\title{
First record of Trachyderes succinctus succinctus (Linnaeus, 1758) (Coleoptera: Cerambycidae) in Khaya ivorensis A. Chev. (Meliaceae) in Brazil
}

\author{
R. T. Fujihara ${ }^{a}$ (D), R. A. G. Viani ${ }^{a}$ (D) and M. Savaris ${ }^{b}$ \\ ${ }^{a}$ Centro de Ciências Agrárias, Universidade Federal de São Carlos - UFSCar, Rodovia Anhanguera, Km 174, \\ CEP 13600-970, Araras, SP, Brasil \\ 'Departamento de Entomologia e Acarologia, Escola Superior de Agricultura "Luiz de Queiroz" - ESALQ, \\ Universidade de São Paulo - USP, CEP 13418-900, Piracicaba, SP, Brasil \\ *e-mail:rtfujihara@ufscar.br
}

Received: April 27, 2019 - Accepted: September 10, 2019 - Distributed: February 28, 2021

(With 1 figure)

The genus Khaya A. Juss. (Meliaceae) comprises six species of mahogany from Africa and Madagascar (The Plant List, 2013), and among them, Khaya ivorensis A. Chev. and Khaya senegalensis (Desv.) A. Juss. were introduced in Brazil to substitute the Brazilian mahogany Swietenia macrophylla King (Meliaceae) (Gaparotto et al., 2001). The African mahogany is a highly desired wood for the furniture and navy industry. The bark is used in dyeing and tanning leather, and in some African countries, for medicines purposes, as repel and to kill mosquitoes and to manage malaria (Taylor, 1960; Opuni-Frimpong et al., 2008; Zhang et al., 2009; Tepongning et al., 2013).

The longhorn beetle, Trachyderes succinctus succinctus (Linnaeus, 1758) (Coleoptera: Cerambycidae) is widely distributed in America, since Argentina through Mexico (Barreto et al., 2013; Monné and Chaboo, 2015). In Brazil, this beetle has been recorded throughout the country (15 Brazilian states), including forest and savanna landscapes (Silva et al., 1968; Maes et al., 2010; Barreto et al., 2013).

We report the first record of T. succinctus succinctus damaging $K$. ivorensis and the second report of a tree from the Meliaceae family in Brazil, which encompasses many timber tree species explored and grown in plantations in the tropics.

The study was realized in a $K$. ivorensis plantation in an experimental area (about 400 trees, 1 ha, spaced $5 \times 5 \mathrm{~m}$ ) of the Federal University of São Carlos in Araras, São Paulo, Brazil (22³1'15'S 47³8'38'W). The climate is Cwa in the Köppen classification, with a rainy and hot summer, and a dry winter. The vegetation type in the region is the Seasonal Semideciduous Forest, a closed-canopy forest in the Atlantic Forest with abundant deciduous and semi-deciduous trees and shrubs, which lose their leaves during the driest months (April to August) (Amazonas et al., 2017). Sugarcane, corn and soybean crops, eucalyptus plantations, and forest restoration sites surround the K. ivorensis plantation, which was done in April 2013.

During a pruning at the experimental plantation in July 2018, we found $K$. ivorensis branches with damage (Figure $1 \mathrm{~A}-\mathrm{C}$, indicated by white arrow) and larvae (Figure 1F, G). The branches were stored and the emerged specimens were identified as $T$. succinctus succinctus $(1 \hat{0}, 1 q+1$ larvae) (Figure $1 \mathrm{D}-\mathrm{G})$, with the aid of entomological keys and comparison with other specimens from the Museu de Entomologia "Luiz de Queiroz" reference collection (ESALQ/USP). The specimens were registered in the Museum database (Silveira Neto et al., 2019) with the numbers MELQ 3903-1, MELQ 3903-2 and MELQ 3903-3.

The adults of T. succinctus succinctus bore into the wood of dead plants or already fallen trunks (Lima, 1955). The females lay their eggs into tree trunks (Sinavimo, 2019) and the larval eclosion occurs between six to eight days after oviposition (Penteado-Dias, 1987). The larvae feed inside of trunks and branches, opening holes (Figure $1 \mathrm{~A}-\mathrm{C}$, indicated by white arrow) that prevent the normal translocation of sap in the plant (Sinavimo, 2019). Sometimes it is possible to find small excrement granules inside the holes, which are the larval feed waste (Figure 1C, indicated by black arrow). The life cycle (egg-larva-pupa-adult) is completed in six months (Penteado-Dias, 1987).

Considering that T. succinctus succinctus is a generalist species with high colonization capacities, it is likely that in periods of increased populations, these beetle may seek alternative hosts such as $K$. ivorensis. With this work, we expanded the lists of the beetle $T$. succinctus succinctus hosts as well as of the $K$. ivorensis pests. We advocate this pest now requires its integration into African mahogany pest monitoring programs, as well as further investigations and attention on pests that can attack this and other African mahogany species recently introduced in Brazil. 

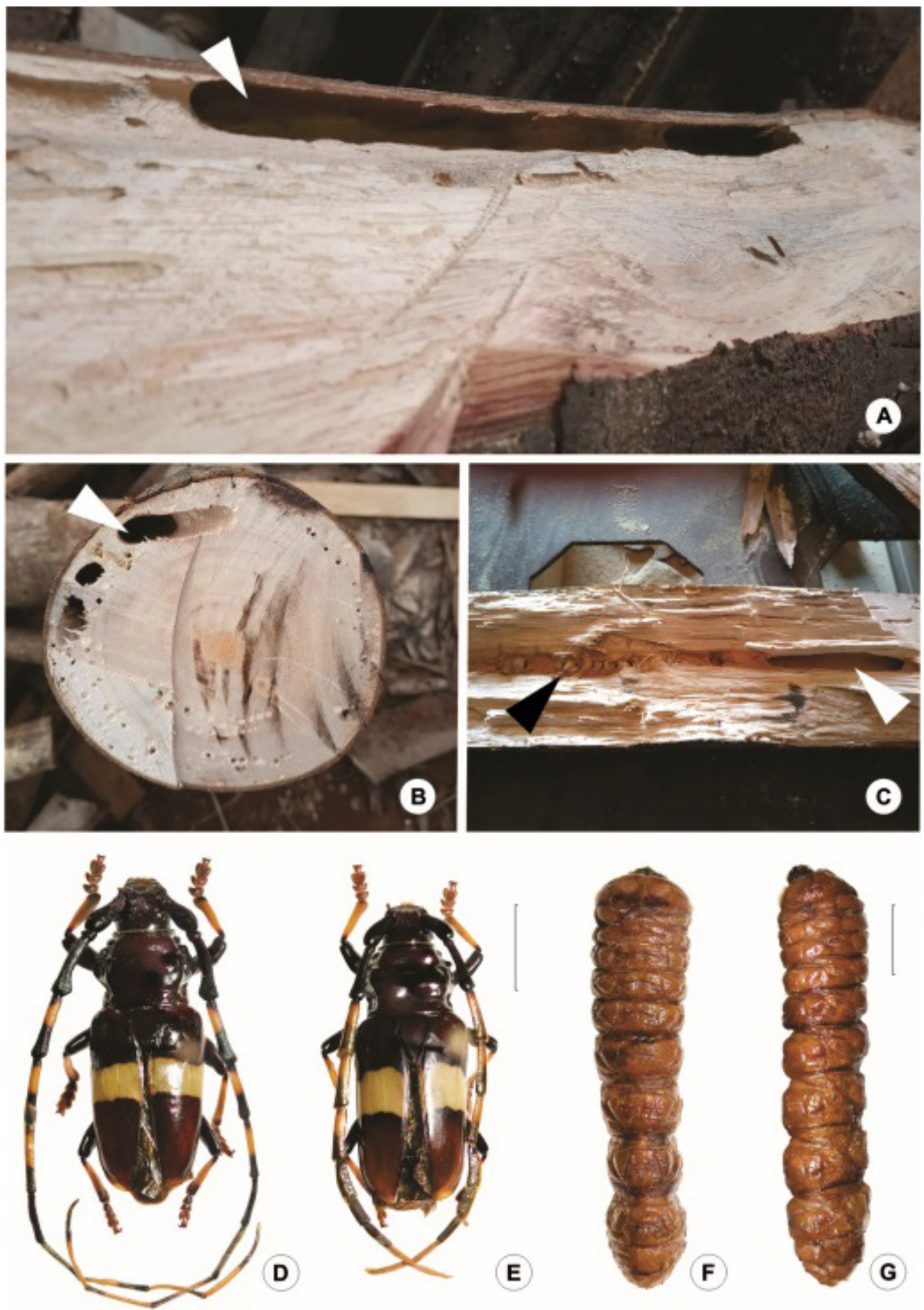

Figure 1. Damage, adults and larvae of Trachyderes succinctus succinctus (Linnaeus, 1758). (A, B) holes in trunks and branches of Khaya ivorensis A. Chev. made by larvae, indicated by white arrow; (C) hole with larval feed waste, indicated by black arrow; (D) Habitus of male, dorsal view; (E) Habitus of female, dorsal view. Scale bar = $1 \mathrm{~cm}$; (F) Larvae, dorsal view; (G) Larvae, lateral view. Scale bar $=1 \mathrm{~cm}$. 


\section{Acknowledgements}

We thank the Programa de Pós-graduação em Agricultura e Ambiente PPGAA/UFSCar and the Programa de Pós-graduação em Entomologia USP/ESALQ. We also acknowledge the two anonymous reviewers and the academic editor for improving the manuscript.

\section{References}

AMAZONAS, N.T., VIANI, R.A.G., REGO, M.G.A., CAMARGO, F.F., FUJIHARA, R.T. and VALSECHI, O.A., 2017. Soil macrofauna density and diversity across a chronosequence of tropical forest restoration in Southeastern Brazil. Brazilian Journal of Biology = Revista Brasileira de Biologia, vol. 78, no. 3, pp. 449-456. http://dx.doi.org/10.1590/1519-6984.169014. PMid:29185609.

BARRETO, M.R., MACHINER, R. and SMIDERLE, E.C., 2013. Cerambycinae (Coleoptera, Cerambycidae) em Mato Grosso, Brasil. Biota Neotropica, vol. 13, no. 1, pp. 331-335. http://dx.doi. org/10.1590/S1676-06032013000100032.

GAPAROTTO, L., HANADA, R.E., ALBUQUERQUE, F.C. and DUARTE, M.L.R., 2001. Mancha areolada causada por Thanatephorus cucumeris em mogno africano. Fitopatologia Brasileira, vol. 26, no. 3, pp. 660-661. http://dx.doi.org/10.1590/ S0100-41582001000300015.

LIMA, A.C., 1955. Insetos do Brasil. Rio de Janeiro: Escola Nacional de Agricultura, 289 p. Tomo 9. Coleópteros $3^{\mathrm{a}}$ parte.

MAES, J.M., VAN DEN BERGHE, E., DAUBER, D., AUDUREAU, A., NEARNS, E., SKILMAN, F., HEFFERN, D. and MONNE, M., 2010. Catálogo de los Cerambycidae de Nicaragua. Parte II - Cerambycinae. Revista Nicaraguense Entomologica, vol. 70, no. 2, pp. 1-640.

MONNÉ, M.A. and CHABOO, C.S., 2015. Beetles (Coleoptera) of Peru: a survey of the families. Cerambycidae, Disteniidae, Vesperidae. Journal of the Kansas Entomological Society, vol. 88, no. 1, pp. 34-120. http://dx.doi.org/10.2317/JKES1410.13.1.

OPUNI-FRIMPONG, E., KARNOSKY, D.F., STORER, A.J. and COBBINAH, J.R., 2008. Key roles of leaves, stockplant age, and auxin concentration in vegetative propagation of two African mahoganies: Khaya anthotheca Welw. and Khaya ivorensis A. Chev. New Forests, vol. 36, no. 2, pp. 115-123. http://dx.doi. org/10.1007/s11056-008-9087-6.

PENTEADO-DIAS, A.M., 1987. Biologia e ontogenia de Trachyderes striatus (Fabricius) (Coleoptera, Cerambycidae). Revista Brasileira de Zoologia, vol. 4, no. 1, pp. 47-53. http:// dx.doi.org/10.1590/S0101-81751987000100004.

SILVA, A.G.A., GONÇALVES, C.R., GALVÃO, D.M., GONÇALVES, A.J.L., GOMES, J., SILVA, M.N. and SIMONI, L., 1968. Quarto catálogo dos insetos que vivem nas plantas do Brasil: seus parasitos e predadores. Rio de Janeiro: Laboratório Central de Patologia Vegetal, Ministério da Agricultura. Parte 2, Tomo 1.

SILVEIRA NETO, S., ZUCCHI, R.A., MORAES, R.C.B. and LAI REYES, A.E., 2019 [viewed 24 April 2019]. Museu de Entomologia "Luiz de Queiroz" [online]. Piracicaba: ESALQUSP. Available from: http://www.lea.esalq.usp.br/me/

SISTEMA NACIONAL ARGENTINO DE VIGILANCIA Y MONITOREO DE PLAGAS - SINAVIMO, 2019 [viewed 25 June 2019]. Trachyderes succinctus [online]. Buenos Aires. Available from: https://www.sinavimo.gov.ar

TAYLOR, C.J., 1960. Synecology and silviculture in Ghana. Edinburgh: Thomas Nelson and Sons.

TEPONGNING, R.S., YERBANGA, S.R., DORI, G.U., LUCANTONI, L., LUPIDI, G. and HABLUETZEL, A., 2013. In vivo efficacy and toxicity studies on Erythrina senegalensis and Khaya ivorensis used as herbal remedies for malaria prevention in Cameroon. European Journal of Medicinal Plants, vol. 3, no. 3, pp. 454-464. http://dx.doi.org/10.9734/ EJMP/2013/3928.

THE PLANT LIST, 2013 [viewed 7 July 2019]. Version 1.1 [online]. Available from: http://www.theplantlist.org/

ZHANG, B., YANG, S.P., YIN, S., ZHANG, C.R., WU, Y. and YUE, J.M., 2009. Limonoids from Khaya ivorensis. Phytochemistry, vol. 70, no. 10, pp. 1305-1308. http://dx.doi.org/10.1016/j. phytochem.2009.07.016. PMid:19666181. 